\title{
Groundwater Zoning for the North-West Region of Bangladesh
}

\author{
Md. Iquebal Hossain ${ }^{1,2, ~ *, ~ N i a m u l ~ B a r i ~}{ }^{1}$, Iqbal Matin ${ }^{1}$ \\ ${ }^{1}$ Department of Civil Engineering, Rajshahi University of Engineering \& Technology, Rajshahi, Bangladesh \\ ${ }^{2}$ Barind Multipurpose Development Authority, Rajshahi, Bangladesh \\ Email address: \\ iquebal_hossain@yahoo.com (Md. I. Hossain), niamulbari@gmail.com (N. Bari), imatinbd@yahoo.com (I. Matin) \\ ${ }^{*}$ Corresponding author
}

\section{To cite this article:}

Md. Iquebal Hossain, Niamul Bari, Iqbal Matin. Groundwater Zoning for the North-West Region of Bangladesh. Hydrology.

Vol. 8, No. 3, 2020, pp. 52-61. doi: 10.11648/j.hyd.20200803.13

Received: August 29, 2020; Accepted: September 14, 2020; Published: October 26, 2020

\begin{abstract}
For proper planning and management of groundwater of an area, zoning of groundwater is essential which can be done by using modeling tool. Groundwater zoning is very important, especially for irrigation project as well as drinking needs. So, the present study aims to assess the zoning of groundwater at the Joypurhat district located in the north-west region of Bangladesh. MIKE SHE modelling tool has been used for this study. A groundwater flow model has been developed with calibrating for the period of 2001 to 2006 and validating for 1995 to 2000. As Hand Tube Well (HTW) and Shallow Tube Well (STW) operate under suction mode and they can operate with full efficiency when groundwater table remains within $6 \mathrm{~m}$ from ground surface, this depth has been considered as the safe yield criteria. Groundwater zoning has been done based on the safe yield criteria. At the end of April groundwater level goes below $6 \mathrm{~m}$ from the ground surface in Kali, Khetlal, Akkelpur and Panchbibi upazila. These areas are considered as deep zone. On the contrary, Joypurhat Sadarupazila is considered as the shallow zone because groundwater level remains within the $6 \mathrm{~m}$ from the ground surface in this upazila.
\end{abstract}

Keywords: Groundwater, Groundwater Zoning, Aquifer, Mathematical Modelling, Hydraulic Conductivity, Specific Yield, North-West, Bangladesh

\section{Introduction}

Bangladesh is recognized as a lower riparian country of the Ganges-Brahmaputra-Meghna (GBM) Deltaic region in South Asia ranked second in the list of most vulnerable countries in the world. Here efforts to reduce poverty are constrained due to reduction in availability of fresh water and food security as lives and livelihoods depend on water and agriculture. Presently groundwater based irrigation is adopted to cultivate high-yielding rice variety during dry season in South Asia as Bangladesh is the world's fourth biggest rice-producing country $[1,2]$. Since the 1970 s and 80 s green revolution technologies of improved irrigation infrastructure, access to chemical fertilisers and pesticides, increased mechanisation and improved varieties have greatly increased rice yields in Bangladesh [3]. Here agriculture contributes nearly $20 \%$ of the GDP as rice crops cover $75 \%$ of the cropped areas and contribute over $95 \%$ to the total food grain production. In Bangladesh, the area irrigated by groundwater (as a fraction of total irrigated area) grew from $4 \%$ to $70 \%$ between 1972 and 1999 [4]. The significant growth in the country's irrigated agriculture has happened in the past decade which resulted ever increasing demand of finally leads to water shortage $[5,6]$. The study area located in the north-west region of Bangladesh is mainly drought prone. Groundwater is the main source of irrigation and drinking use as the surface water sources are very limited. Due to limited scope of surface water during dry season, in most of the study area, irrigation is done using groundwater by means of DTWs and STWs [7]. The location map and the digital elevation model of the study area are shown in Figure 1 and Figure 2. The study area 
includes entire five upazilas of Joypurhat district (Upazila and district are the second and third tiers of administrative units in Bangladesh). Topography of the study area varies from $24 \mathrm{~m}$ PWD in Panchbibi to $14.4 \mathrm{~m}$ PWD in Akkelpur. The area is almost flood free making it suitable for round the year cultivation. The study area is relatively flat, sloping from North to South. Top soil of the study area is mainly clay and the aquifer properties like Transmissivity varies from $1240 \mathrm{~m}^{2}$ /day to $1700 \mathrm{~m}^{2} /$ day in the study area [8]. Like the other natural calamities and disasters such as floods or cyclones $[9,10]$, droughts affect the north-western parts including the study area of the country more severely when monsoon fails. The ever increasing demand of water, caused by climate change, urbanization and population growth, poses increasing stress on groundwater as a resource $[11,12]$.
Moreover more than 15000 installed Deep Tube wells (DTWs) [13] have caused the over exploitation of groundwater. Agriculture as well as irrigation and urban water demands cause the over exploitation of groundwater [14-16]. This over exploitation is the cause of declining the ground water level (GWL) [17, 18]. The excessive withdrawal of groundwater also put threat on its resource sustainability [19-22]. So for sustainable use of groundwater in planned way proper zoning of groundwater is a vital issue. The physically distributed hydrological modeling tool like MIKE SHE [23] \& MIKE 11 [24] is very useful for the for the assessment of potential groundwater and surface water resources IWM $[25,26,8,27]$. So for the study MIKE SHE modeling tool has been used.

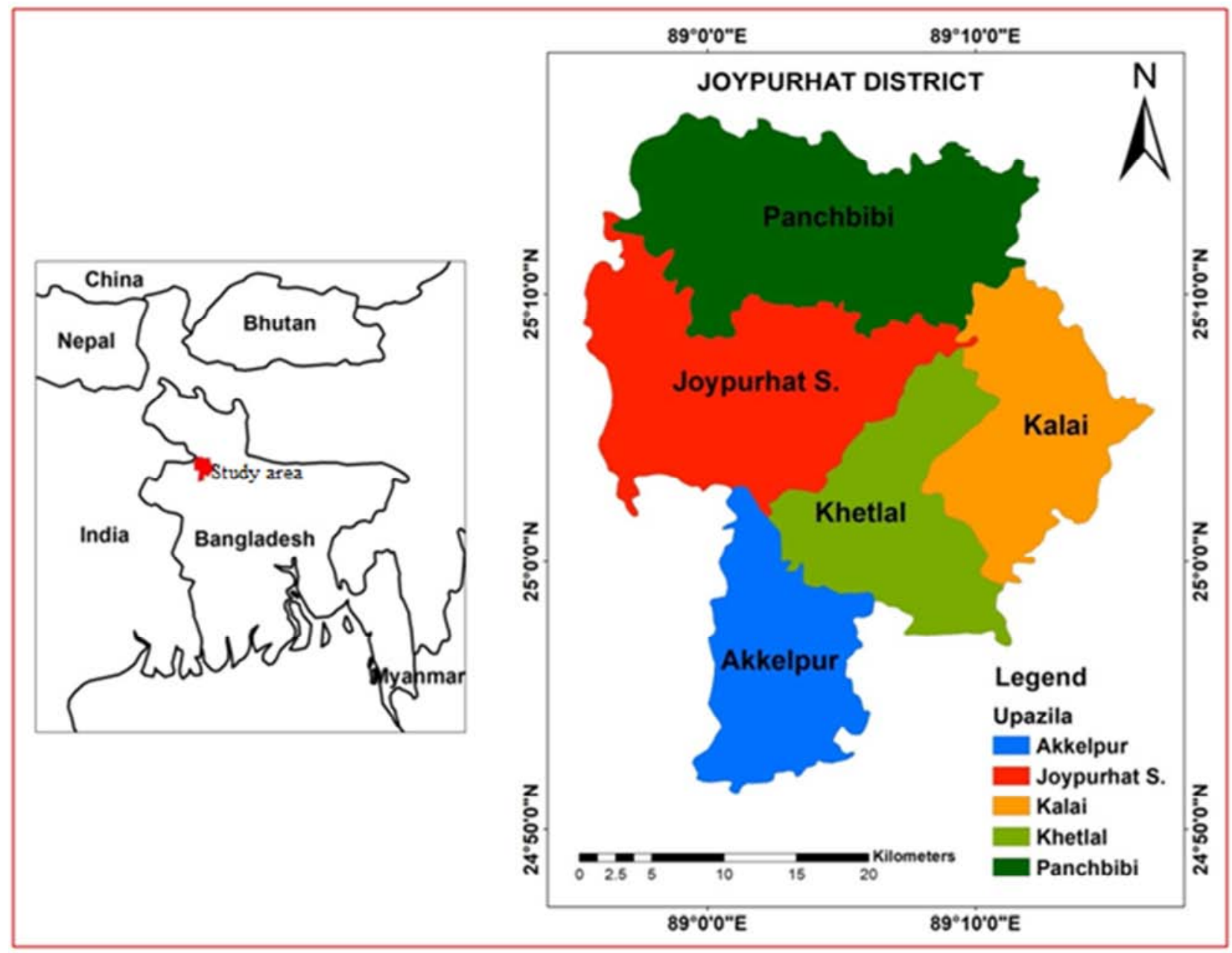

Figure 1. Location map of the study area.

\section{Methodology}

Conceptual development of a model is the initial stage of the groundwater model study. Model refinements are based on the availability and quality of data, hydrogeological understanding and modelling study scope. The general approach has been as shown through the flow chart as in the Figure 3. 


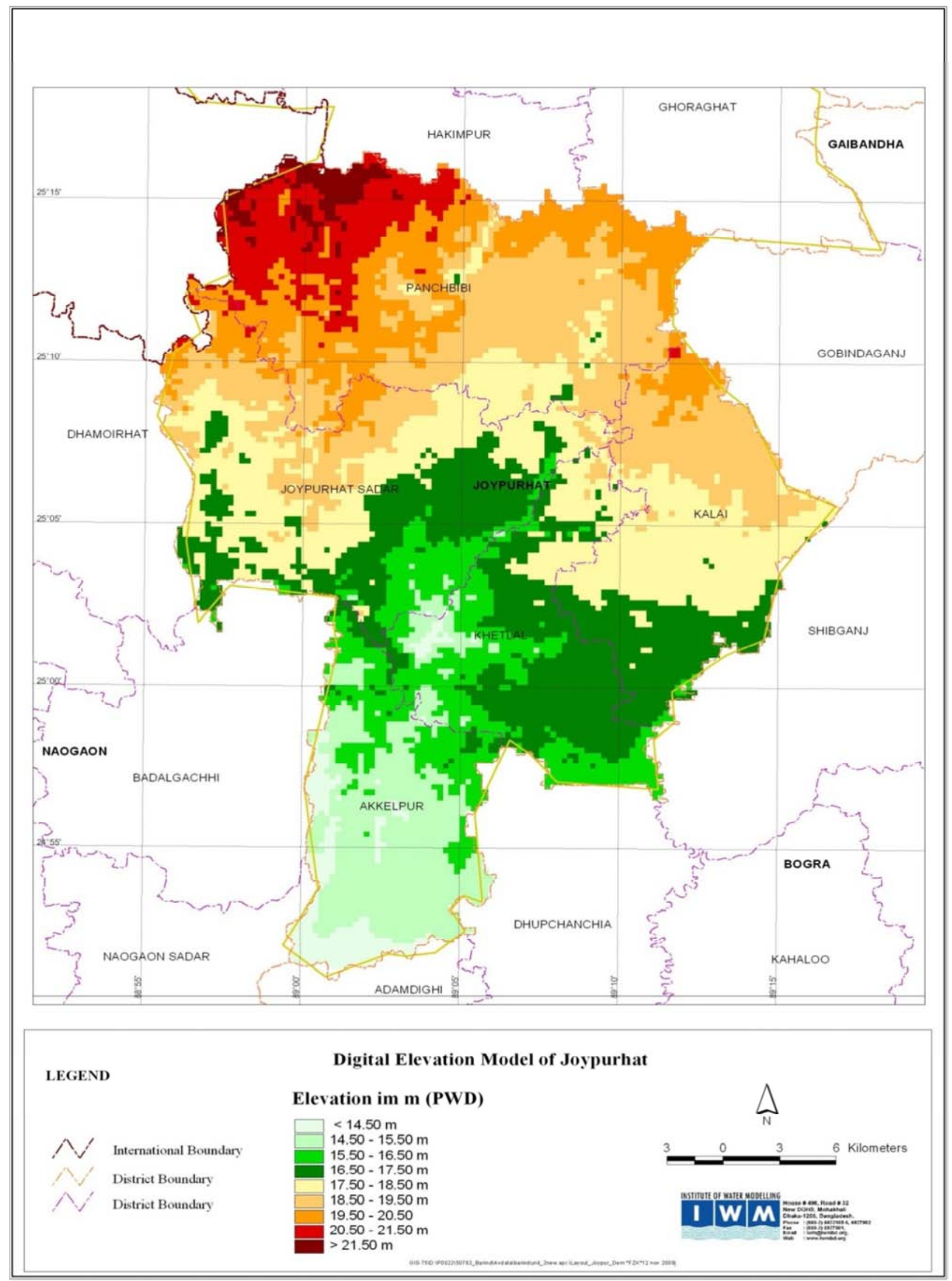

Figure 2. Digital elevation model of the study area. 


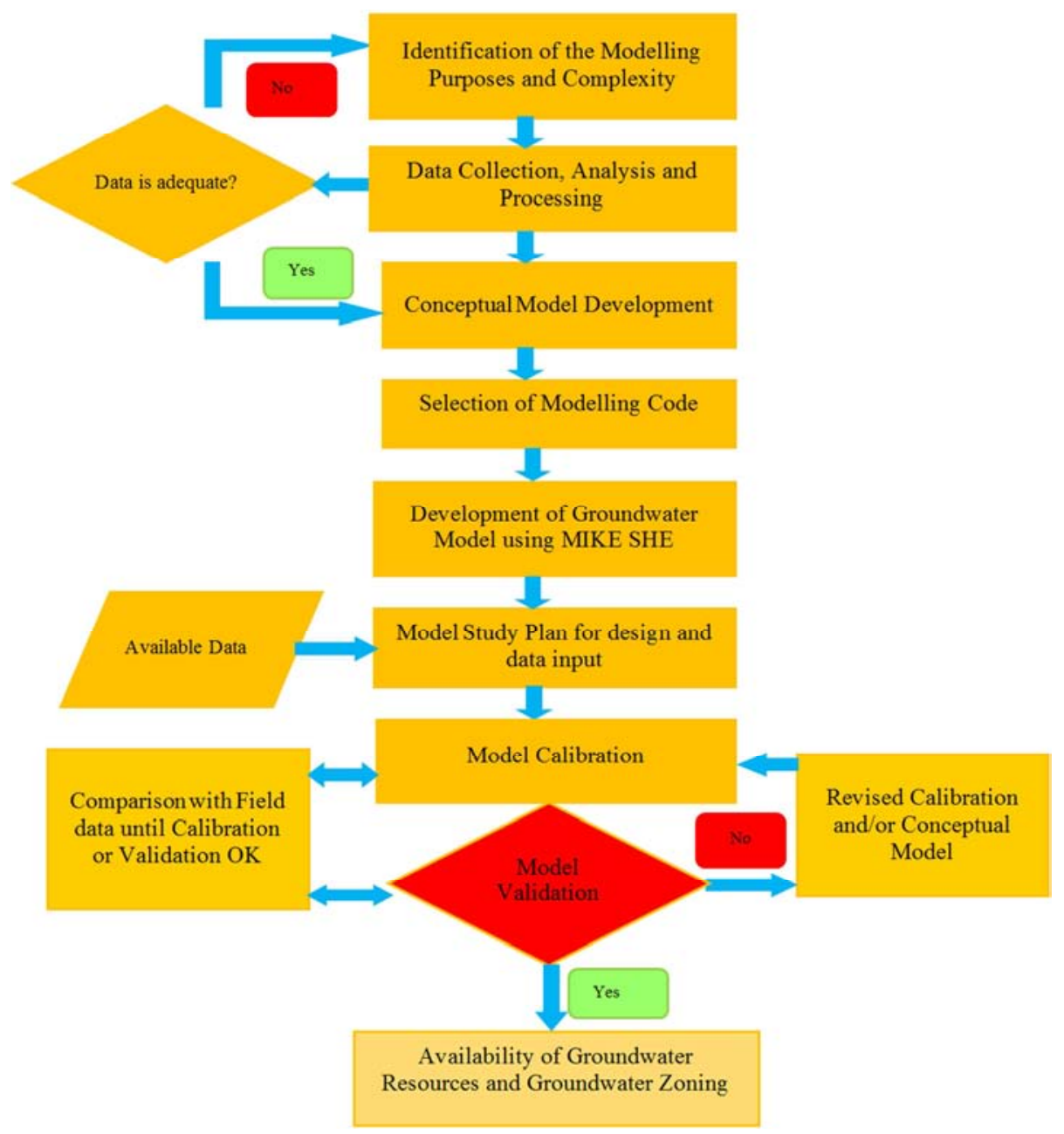

Figure 3. Detail flow chartfor the study.

To develop the groundwater model using MIKE SHE, rainfall and Evaporation data for the period of 1975 to 2006, groundwater level data, lithological and aquifer properties data and Land use data have been collected from Institute of Water Modelling (IWM) and Bangladesh Water Development Board (BWDB) and used.

Yearly mean rainfall of the 9 rainfall station is shown in Figure 4 . The figure 4 shows the average of the mean annual rainfall is around $1800 \mathrm{~mm}$.

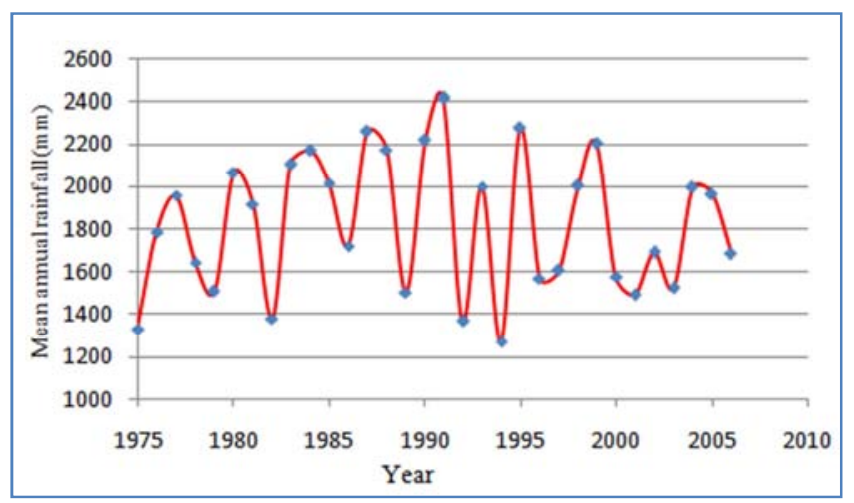

Figure 4. Mean annual rainfall of the study area.
The average annual evaporation of the study area is around $1060 \mathrm{~mm}$. Groundwater observation level data is an important parameter to the groundwater model as it is used for the generation of boundary and initial condition of the model and for calibration and validation of the model. Available groundwater level data have been collected from the BWDB observation wells and used for the model. The groundwater level fluctuation data of Joypurhat Sadarupazila is shown in Figure 5.

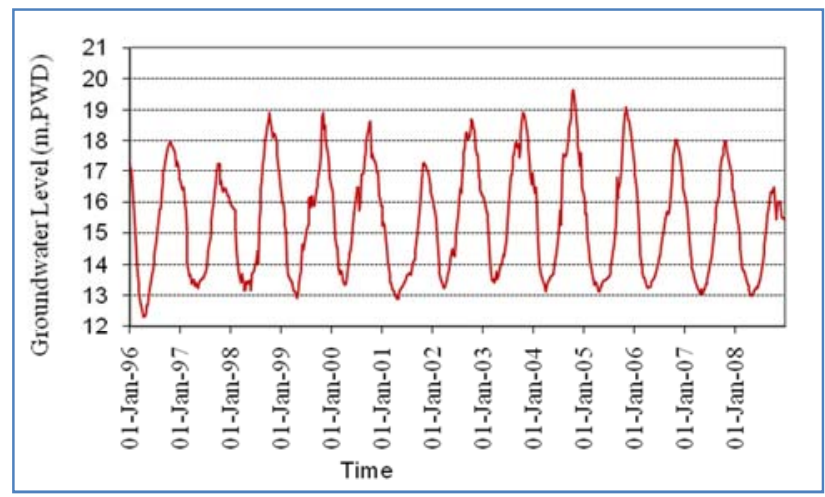

Figure 5. Fluctuation of groundwater level atJoypurhat Sadar. 
Test boring data (litholog data) have been collected from IWM. The main aquifers of the study area range from $15 \mathrm{~m}$ to $24 \mathrm{~m}$ and the screenable thickness of aquifers range from $33 \mathrm{~m}$ to $46 \mathrm{~m}$ within the depth range $57 \mathrm{~m}$ to $87 \mathrm{~m}$ (Figure 6).

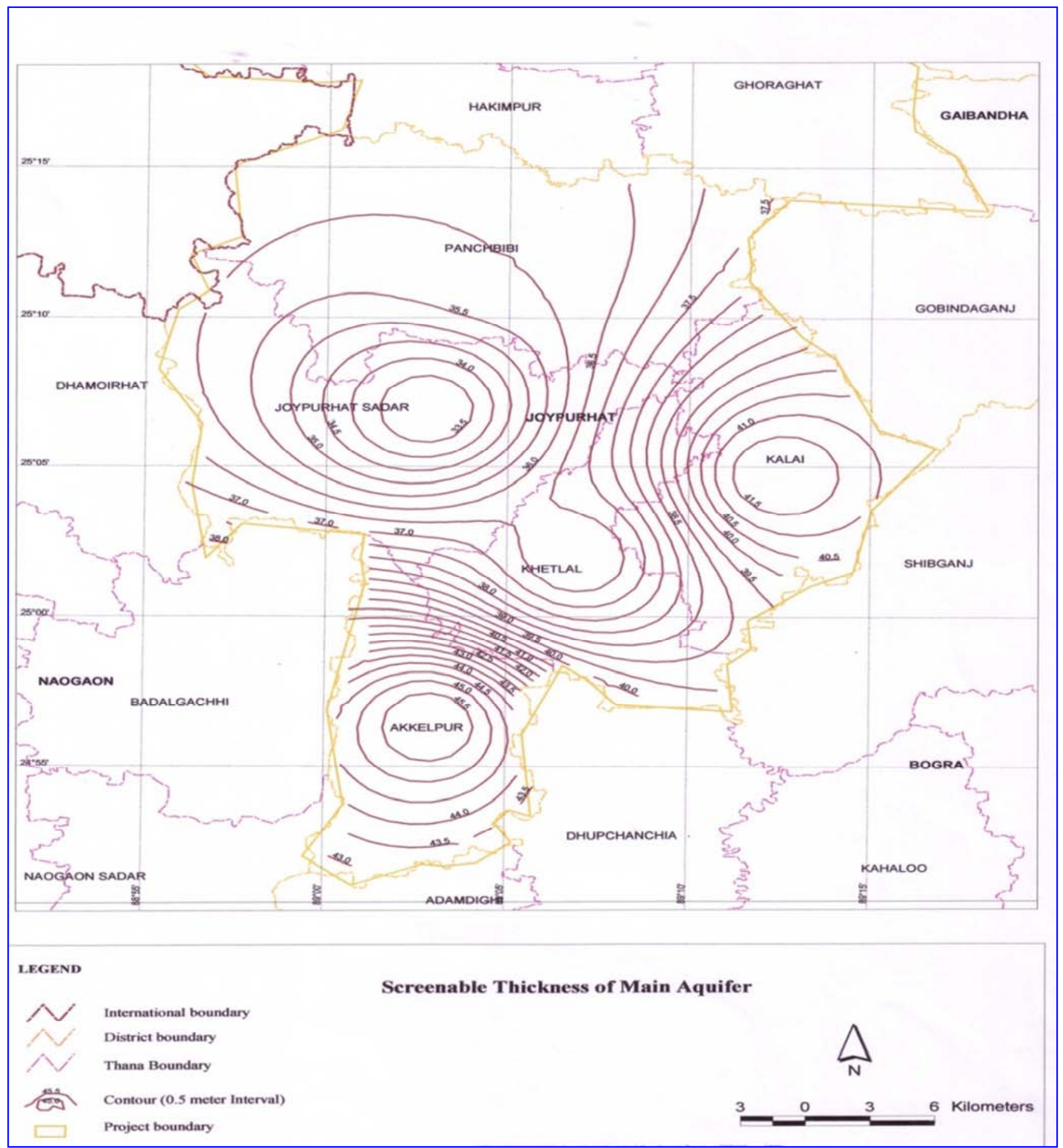

Figure 6. Screenable thickness of main aquifer of the study area.

The hydraulic properties of aquifer have been collected from IWM office which is shown in Figure 7 (a-c). Figure shows that Hydraulic Conductivity ranges from $40 \mathrm{~m} /$ day to
$45 \mathrm{~m} /$ day, Specific Yield values varies from 0.03 to 0.10 and Transmissivity varies from $1300 \mathrm{~m}^{2} /$ day to $1600 \mathrm{~m}^{2} /$ day in the study area. 

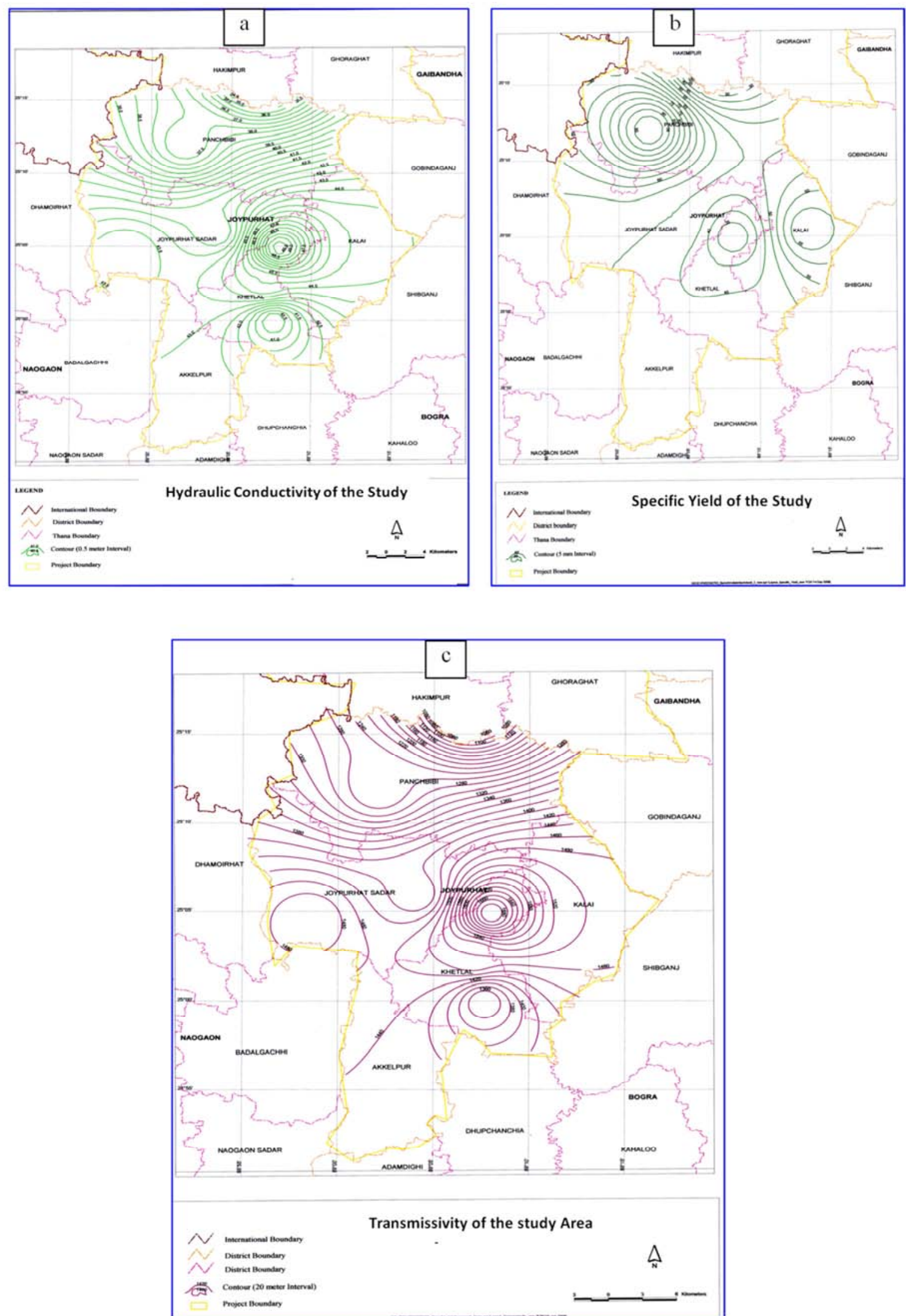

Figure 7. Contour map of Hydraulic conductivity (a), Specific yield (b) and Transmissivity (c). 


\subsection{Model Setup}

Model setup involves a geometrical description and specification of the hydrological system of the study area.

The study area has been discretized into grids of $1000 \mathrm{~m}$ by $1000 \mathrm{~m}$ square cells as shown in Figure 8 . The model has 48rows and 37 columns and total of 1776active cells in each layer. Among the grid cells, 151 grids are the boundary cells and the rest are computational cells.

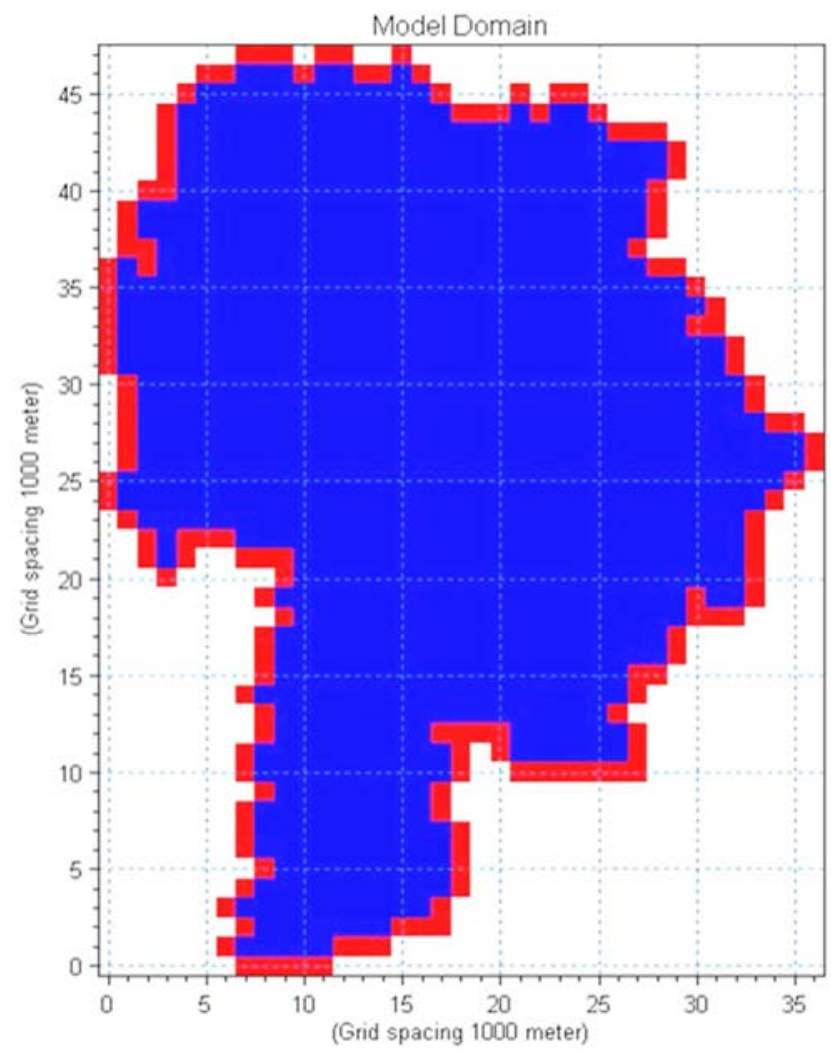

Figure 8. Discretization of the model domain.

\subsection{Model Calibration and Validation}

Groundwater level data have been used for the calibration and validation purposes. The model has been calibrated for the period 2001 to 2006 and validated for the period 1995 to 2000. Calibration and Validation curve of groundwater level for the observation well BO-008 at Panchbibi is shown in Figure 9 ( $a \& b)$.

The Figure 9 shows that the overall calibration of the present model is acceptable and the validation plots depict a good correlation between the observed and the simulated values.

\subsection{Selection of Design Year}

In this study, design year has been selected based on return period of mean annual rainfall of the study area. The annual rainfall recorded for the period of 32 years (1975-2006) has been considered for statistical analysis. The year 2002 has been selected as the design year based on the statistical analysis.

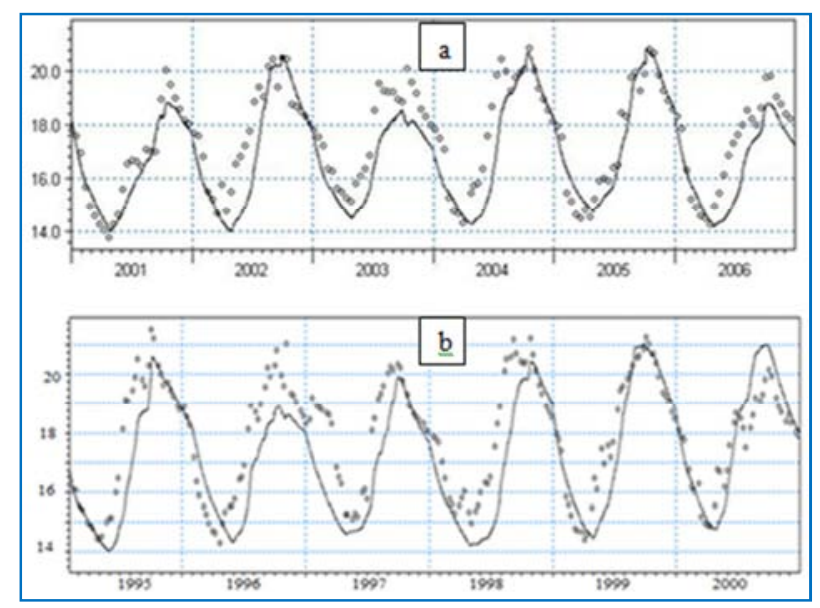

Figure 9. Calibration (a) and validation (b) curve of groundwater level for the observation well $\mathrm{BO}-008$.

\subsection{Safe Yield Criteria}

Hand Tube Well (HTW) and Shallow Tube Well (STW) operate under suction mode. The HTW and STW become completely inoperable condition when depth to groundwater table goes beyond suction limit, i.e., $7 \mathrm{~m}$ from ground surface. On the other hand HTW and STW can operate with full efficiency when groundwater table remains within $6 \mathrm{~m}$ from ground surface. If water table remains within 6 to $7 \mathrm{~m}$ depth, HTW and STW still can abstract water but efficiency will be less and more energy will be required. Considering these facts, $6 \mathrm{~m}$ depth to groundwater table from ground surface has been considered as safe yield limit to ensure the drinking and irrigation water supply through HTW and STW respectively with full operational efficiency.

\subsection{Groundwater Resource Assessment}

In the study area groundwater resource has been calculated depending on recharge characteristics and safe yield criteria. To calculate the groundwater resource, the availability of groundwater within the allowable depths are estimated based on available saturated thickness up to this depth multiplied by specific yield of the area:

$$
\mathrm{V}_{\mathrm{w}}=\mathrm{Ax} \Delta h \times S_{y}
$$

Here, $\mathrm{V}_{\mathrm{w}}$ is the volume of water, $\Delta \mathrm{h}$ is the saturated thickness within allowable depths and $\mathrm{S}_{\mathrm{y}}$ is the specific yield of the aquifer.

Groundwater resources availability within the $6 \mathrm{~m}$ depth have been calculated depending on available saturated thickness up to $6 \mathrm{~m}$ depth multiplied by specific yield.

\section{Result and Discussion}

\subsection{Available Groundwater Resources Before Irrigation Period}

Available groundwater resources have been calculated 
based on the saturated thickness and the values of specific yield from the calibrated model. Upazila-wise available groundwater resources upto6m from the ground surface are shown in Table 1.

Table 1. Upazilawise available groundwater resources up to $6 \mathrm{~m}$ depth from the ground surface.

\begin{tabular}{llll}
\hline \multirow{2}{*}{ District } & \multirow{2}{*}{ Upazila } & \multicolumn{2}{c}{ Available groundwater resource } \\
\cline { 3 - 4 } & & $\mathbf{m m}$ & $\mathbf{M m}^{\mathbf{3}}$ \\
\hline \multirow{3}{*}{ Joypurhat } & Akkelpur & 231 & 34 \\
& Joypurhat Sadar & 456 & 112 \\
& Kalai & 511 & 84 \\
& Khetlal & 435 & 63 \\
Total & Panchbibi & 411 & 113 \\
& & 2044 & 406 \\
\hline
\end{tabular}

\subsection{Groundwater Zoning}

A simulated groundwater depth map has been prepared at the end of irrigation season that is at the end of April as shown in Figure 10. It is observed that Groundwater level goes beyond $6 \mathrm{~m}$ from the ground surface in the upazilas of Kalai, Khetlal, Akkelpur and Panchbibi. Hence these areas are not suitable for STW irrigation. So, these areas are considered as deep zone. In Joypurhat Sadarupazila the groundwater level is within 6 from the ground surface. However, groundwater depth up to $6 \mathrm{~m}$ is considered as suction limit for STW and HTW without constraint. Based on this criterion, the study area is divided into shallow and deep zone from groundwater abstraction point of view. However, in shallow zone, abstraction by DTW is also possible. So it can be considered as mixed mode zone. Figure 10 shows the groundwater zoning map of entire study area. The zoning map shows that, maximum part of the study area falls under deep zone and some portions of Joypurhat Sadar and Panchbibi zone fall under shallow zone.

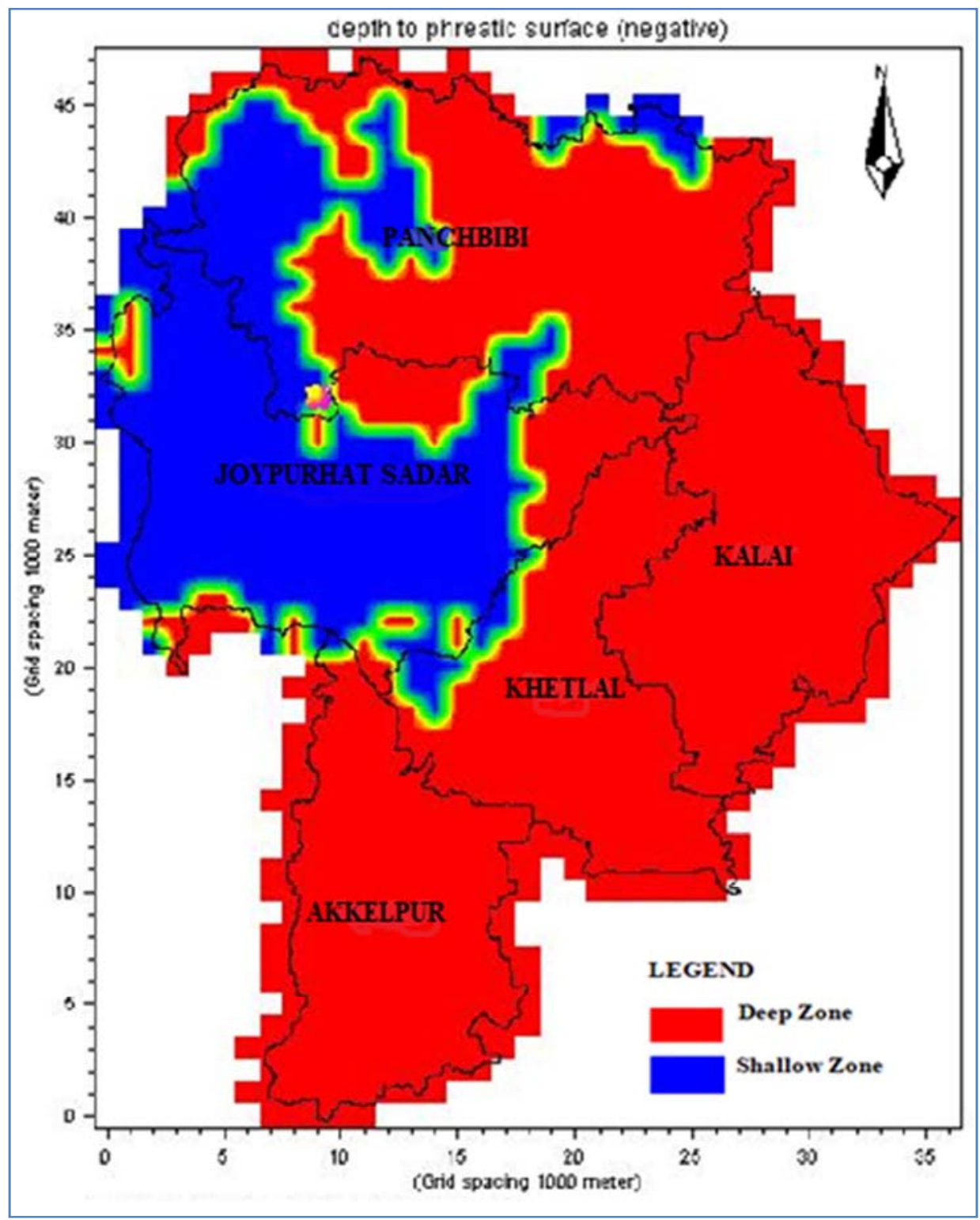

Figure 10. Groundwater zoning map of the study area. 


\section{Conclusions}

Development of the model has been done with satisfactory calibration and validation and available groundwater resource for the study area has been calculated based on the maximum groundwater table $6 \mathrm{~m}$ from ground surface. According to the depth of groundwater table, groundwater zone has been divided into Shallow zone and Deep zone. The upazilas Kalai, Khetlal, Akkelpur and Panchbibifall under Deep zone while the upazila Joypurhat is in Shallow zone. The Shallow zone may not be limited to STW use only, it may be deemed as a mixed zone where both the STW and DTW can be used. Any research output depends on the availability, adequacy and reliability of data. Moreover, there are lots of uncertainties in different assumptions for the estimation of recharge. More research and study are needed.

\section{Conflicts of Interest}

All the authors do not have any possible conflicts of interest.

\section{Acknowledgements}

The authors are grateful to Barind Multipurpose Development Authority (BMDA) for the support with different data and cooperation.

\section{References}

[1] C. A. Scott, and B. Sharma, "Energy supply and the expansion of groundwater irrigation in the Indus-Ganges Basin". International Journal of River Basin Management. 2009, 7 (2) pp. 119-124, doi: 10.1080/15715124.2009.9635374.

[2] IRRI (International Rice Research Institute), World rice statistics (WRS), Manila, Philippines, 2010.

[3] K. Molitor and B. Pritchard, "The effects of food price changes on smallholder production and consumption decisionmaking: evidence from Bangladesh", Geographical Research, 2017, 55 (2) pp. 206-216.

[4] M. Mainuddin, "Groundwater irrigation in Bangladesh: Tool for poverty Alleviation or Cause of Mass Poisoning", Published in the Proceeding of the Symposium on Intensive use of Groundwater: Challenges and Opportunities, Valencia, Spain. Held on10December to14 December 2002.

[5] M. De Villiers, "Water: the fate of our most precious resource", Mariner Books, Houghton, Mifflin, Boston, 2000.

[6] G. Tsakiris, "Water resources management trends, prospects and limitations", In: Proceedings of the EWRA symposium on water resources management: risks and challenges for the $21 \mathrm{st}$ century, 2-4 September 2004, Izmir, pp. 1-6.

[7] Institute of Water Modelling (IWM), "Survey \& Investigation of Water Resources Management by Mathematical Modelling of Panchagarh, Thakurgaon, Dinajpur \& Joypurhat Integrated Agriculture Development Project Areas", 2015, Final Report, Vol. 1.
[8] Institute of Water Modelling (IWM), "Groundwater Resource Study and Decision Support System Development of Thakurgaon, Panchagarh, Dinajpur, Joypurhat Districts and also Remaining Districts of Rajshahi Division Through Mathematical Model Study", 2009, Final Report, Volume-II.

[9] H. Brammer, "Drought in Bangladesh: lessons for planners and administrators", Disasters, 1987, 1 (1), pp. 21-29.

[10] D. Alexander, "Changing perspectives on natural hazards in Bangladesh," Natural Hazards Observation Journal, 1995, 10 (1), pp. 1-2.

[11] Bouwer, H. Artificial recharge of groundwater: Hydrogeology and engineering. Hydrogeology Journal, 2002, Vol. 10, pp. $121-142$.

[12] J. L. Vanderzalm, D. W. Page, K. E. Barry, P. J. Dillon, “A comparison of the geochemical response to different Managed aquifer recharge operations for injection of urban storm water in a carbonate aquifer", Appl. Geochem. 2010, 25, pp. 13501360 .

[13] Barind Multipurpose Development Authority (BMDA), "Irrigation Status of Rajshahi Division, 2017-2018, Ministry of Agriculture, Govt. of Bangladesh".

[14] L. F. Konikow, and E. Kendy, "Groundwater depletion: A global problem", Hydrogeology Journal, 2005, 13 (1), pp. 317-320.

[15] T. Gleeson, J. Vandersteen, M. A. Sophocleous, M. Taniguchi, W. M. Alley, D. M. Allen and Y. Zhou, "Groundwater sustainability strategies", Nature Geoscience, 2010, 3 (1) pp. 378-379.

[16] H. H. Jaafar, "Feasibility of groundwater recharge dam projects in arid environments" Journal of Hydrology, 2014, 512 (1), pp. 16-26.

[17] Central Ground Water Board (CGWB) Guide on Artificial Recharge to Groundwater. Ministry of Water Resources, New Delhi, India. (cgwb.gov.in/documents/ArtificialRechargeGuide.pdf), 2000.

[18] A. K. Bhattacharya, "Artificial Groundwater Recharge with a special reference to India," International Journal of Research and Reviews in Applied Sciences, 2010, Vol. 4, pp. 2.

[19] C. S. Jahan, Q. H. Mazumder, A. M. M Islam, M. I. Adham, "Impact of Irrigation in Barind Area, NW Bangladesh - An Evaluation Based on the Meteorological Parameters and Fluctuation Trend in Groundwater Table", Journal of Geological Society of India, 2010, vol. 76, pp. 134-142.

[20] A. T. M. S. Rahman, M. Kamruzzaman. C. S. Jahan, Q. H. Mazumder, A. Hossain, "Evaluation of spatio-temporal dynamics of water table in NW Bangladesh - an integrated approach of GIS and statistics", Sustainable Water Resources Management, 2016, 2 (3), pp. 297-312, Doi: 10.1007/s40899016-0057-4.

[21] A. T. M. S. Rahman, M. Kamruzzaman. C. S. Jahan, Q. H. Mazumder, "Long-term trend analysis of water table using 'MAKESENS' model and sustainability of groundwater resources in drought prone Barind Area, NW Bangladesh", Journal of Geological Society of India, 2016, Vol. 87, pp. 179193. 
[22] A. T. M. S. Rahman, M. Kamruzzaman. C. S. Jahan, Q. H. Mazumder, T. Hosono, "Drought Analysis and its Implication in Sustainable Water Resource Management in Barind Area, Bangladesh", Journal of Geological Society of India, 2017, 89 (1), pp. 47-56. Doi: 10.1007/s12594-017-0557-3.

[23] DHI, "MIKE SHE User Manual- Hydrological Modelling System for Groundwater", 1999.

[24] DHI, "MIKE 11User Manual - a Modelling system for Rivers and Channels", 1999.

[25] Institute of Water Modelling (IWM), "Groundwater Management and Zoning Study for repair and Rehabilitation of Deep Tube well Project in Greater Dinajpur District under Post Drought Agricultural Rehabilitation Programme", 2005, Final Report, Volume 1.

[26] Institute of Water Modelling (IWM), "Groundwater Resources Study for Deep Tube Well Installation Project in Barind Area", 2006, Final Report, Volume 1.

[27] Institute of Water Modelling (IWM), "Groundwater Resources Study and Interactive Information System (IIS) Development of Pabna, Sirajgonj, Bogra, Gaibandha, Rangpur, Kurigram, Nilphamari and Lalmonirhat Districts through Mathematical Model Study", 2014, Final Report, Volume 1. 